\title{
Nickel-Doped Cerium Oxide Nanoparticles: Green Synthesis Using Stevia and Protective Effect against Harmful Ultraviolet Rays
}

\author{
Mehrdad Khatami ${ }^{1,2} \oplus$, Mina Sarani ${ }^{1,3}$, Faride Mosazadeh ${ }^{3}$, Mohammadreza Rajabalipour ${ }^{1}$, \\ Alireza Izadi ${ }^{4}$, Meghdad Abdollahpour-Alitappeh ${ }^{5}$ (D), Marcos Augusto Lima Nobre 6 \\ and Fariba Borhani ${ }^{7, *}$ \\ 1 NanoBioEletrochemistry Research Center, Bam University of Medical Sciences, Bam 76617-71967, Iran; \\ mehrdad7khatami@gmail.com (M.K.); minasarani64@gmail.com (M.S.); mmrr1366@yahoo.com (M.R.) \\ 2 Cell Therapy and Regenerative Medicine Comprehensive Center, Kerman University of Medical Sciences, \\ Kerman 7618747653, Iran \\ 3 Students Research Committee, School of Public Health, Bam University of Medical Sciences, \\ Bam 76617-71967, Iran; f.mousazadeh7@gmail.com \\ 4 Department of Medical Parasitology and Mycology, School of Public Health, Tehran University of Medical \\ Sciences, Tehran 14167-53955, Iran; alirezaizadi81@yahoo.com \\ 5 Cellular and Molecular Biology Research Center, Larestan University of Medical Sciences, \\ Larestan 74319-75566, Iran; abdollahpour1983@yahoo.com \\ 6 School of Technology and Sciences, São Paulo State University (Unesp), Presidente Prudente-SP 19060-900, \\ Brazil; marcos.nobre@unesp.br \\ 7 Medical Ethics and Law Research Center, Shahid Beheshti University of Medical Sciences, \\ Tehran 19857-17443, Iran \\ * Correspondence: faribaborhani@msn.com; Tel.: +98-344-421-9074
}

Academic Editors: Francesco Baino and Saeid Kargozar Received: 5 October 2019; Accepted: 18 November 2019; Published: 4 December 2019

\begin{abstract}
Nanoparticles of cerium oxide $\mathrm{CeO}_{2}$ are important nanomaterials with remarkable properties for use in both industrial and non-industrial fields. In a general way, doping of oxide nanometric with transition metals improves the properties of nanoparticles. In this study, nickel- doped cerium oxide nanoparticles were synthesized from Stevia rebaudiana extract. Both doped and non-doped nanoparticles were characterized by X-ray diffraction, Field Emission Scanning Electron Microscopy, Energy Dispersive X-ray, Raman spectroscopy, and Vibrating-Sample Magnetometry analysis. According to X-ray diffraction, Raman and Energy Dispersive X-ray crystalline and single phase of $\mathrm{CeO}_{2}$ and $\mathrm{Ni}$ doped $\mathrm{CeO}_{2}$ nanoparticles exhibiting fluorite structure with F2g mode were synthesized. Field Emission Scanning Electron Microscopy shows that $\mathrm{CeO}_{2}$ and $\mathrm{Ni}$ doped nanoparticles have spherical shape and sizes ranging of 8 to $10 \mathrm{~nm}$. Ni doping of $\mathrm{CeO}_{2}$ results in an increasing of magnetic properties. The enhancement of ultraviolet protector character via Ni doping of $\mathrm{CeO}_{2}$ is also discussed.
\end{abstract}

Keywords: Ni-doped $\mathrm{CeO}_{2}$ nanoparticles; Stevia rebaudiana; UV protection; VSM

\section{Introduction}

Nowadays, research and development of products in the nanotechnology field has been steadily increased, in specific due to innovative and beneficial properties of materials at the nanoscale. Furthermore, nanotechnology as a flexible tool can be applied in electrical devices, construction of composite materials, catalysts and antibacterial coatings [1]. Nanoparticles constitute the fundamental structures of nanotechnology [2]. A most relevant feature of nanoparticles stems from their large ratio 
surface-to-volume ratios [2]. Nanoparticles provide a higher surface area-to-volume ratio through reduction of their particle size, which increases their efficacy in biological media. Among oxide type nanomaterials, cerium oxide nanoparticles can be utilized in sensors, catalysts, sunscreens, ultraviolet physical absorbers and sun cells [3,4], because of their high thermal stability, wide band-gap and rapid changing of oxidation states between Ce (III) and Ce (IV) [3].

The human skin acts as an effective barrier against the harmful effects of environmental substances [5]. In addition, exposure to ultraviolet radiation is a key factor to human skin problems such as cracks, burns, immunosuppression, wrinkles, dermatitis, inflammation, aging, hypopigmentation, hyperpigmentation and skin cancers [6]. Sunscreens are one of the most common options for sunlight protection because of their ease of use and higher effectiveness in radiation protection [7]. Mineral sunscreens contain inorganic UV filters, ultraviolet absorbers, like titanium dioxide $\mathrm{TiO}_{2}$ and zinc oxide $\mathrm{ZnO}$, which have been safe and effective [8]. Oxides of the zinc oxide, cerium oxide; titanium dioxide and iron oxide type are UV light absorbers. Some previous studies involving nanoparticles for UV protection have shown that the absorber efficiency of the oxide depends in a major part on the particle size [9]. In addition to the conventional $\mathrm{TiO}_{2}$ and $\mathrm{ZnO}$ filters, the development of new filters has also been carried out to find new consumer products. The next-generation sunscreen filters with advanced features should be more efficient and safer for the health of users and the environment, replacing $\mathrm{TiO}_{2}$ and/or $\mathrm{ZnO}$. At the moment seems that cerium oxide nanoparticles are a promising mineral for use as a UV filter in sunscreen cosmetics [10]. Several methods of chemical synthesis such as sol-gel, precipitation, thermal decomposition have been employed to attain cerium oxide nanoparticles [11-14]. However, a major part of these synthesis methods are not environmentally friendly, making green chemistry methods like the biosynthesis of nanoparticles using plants and plant products fundamental as a function of benefits such as low cost, safe and environmental security [15-25]. In this sense, Stevia rebaudiana (Asteraceae) is a promising plant to support biosynthesis. It is a shrub with a height of one meter. The plant has small leaves that alternate on the stem [26]. The leaves of this plant have diterpene glucosides, which are naturally sweet. Its sweet components are stevioside, steviol bioside, ribodiazide and dalcoside [27]. Recent investigations have shown that this plant has the ability to prepare in a fast and non-toxic way chemically stable iron oxide, zinc oxide and zinc sulfide nanoparticles [28-33].

In this study, a biosynthesis method based on aqueous extract of Stevia to prepare functional nanoparticles was implemented. Syntheses of $\mathrm{CeO}_{2}$ oxide and of $\mathrm{Ni}$-doped $\mathrm{CeO}_{3}$ solid solutions were carried out. UV protection of the resulting products was measures as Sun Protection Factor (SPF).

\section{Results and Discussion}

The X-ray diffraction curves of $\mathrm{CeO}_{2}$ and $\mathrm{Ni}$-doped $\mathrm{CeO}_{2}$ powder are shown in Figure 1. According to JCPDS file 43-1002, all detected diffraction lines correlated to the following Müller indices (111), (200), (220) and (311), ascribed to the fluorite cubic structure. A specific broadening of diffraction lines presents at all diffraction lines indexed was attributed to the nanometric scale of the particles. A slight shift in the angle position of the (111) diffraction line was identified for all diffraction lines of the $\mathrm{CeO}_{2}$ structure doped with $\mathrm{Ni}$. The crystallite size was estimated using Scherrer equation $\mathrm{D}=0.89 \lambda / \beta \cos \theta$; where $D$ is the crystallite size of a particle, $\lambda$ is $X$-ray wavelength, $\beta$ is full width at half maximum height and $\theta$ is the angle of diffraction. All synthesized powders are nanometric in size, being the $\mathrm{CeO}_{2}$ average crystallite size equal to $10.56 \mathrm{~nm}$. The crystallite size as a function of Ni doping level show that crystallite size decreased with increasing of Ni concentration in the cubic structure of $\mathrm{CeO}_{2}$. 


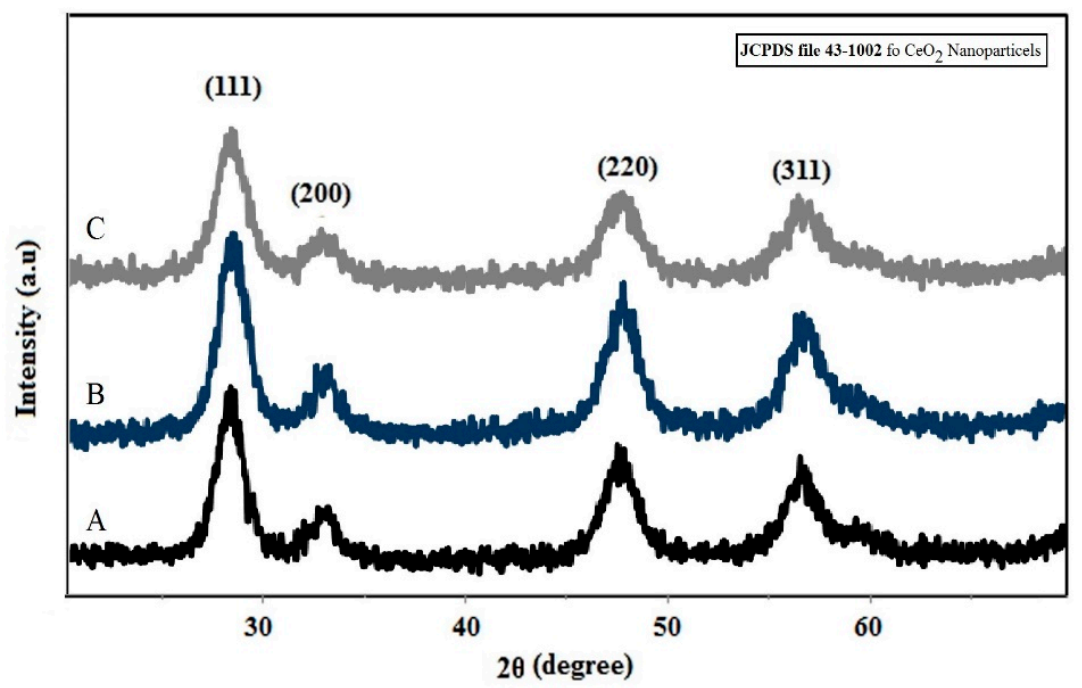

Figure 1. X-Ray diffraction profile of synthesized nanoparticles of (A) $\mathrm{CeO}_{2}$ and $\mathrm{CeO}_{2}$ doped with $1 \% \mathrm{Ni}(\mathbf{B})$ and $3 \% \mathrm{Ni}(\mathbf{C})$ by using S. rebaudiana extract as synthesis medium.

Raman spectroscopy is a powerful tool for characterizing molecular fingerprints and monitoring changes in molecular bond characteristics and their effects on the crystalline structure e.g., stresses and/or strains, crystalline form and crystallinity. $\mathrm{CeO}_{2}$ has a single active mode type $\mathrm{F} 2 \mathrm{~g}$ that is usually positioned at around $463.08 \mathrm{~cm}^{-1}$ [34]. This vibrational mode is related to the structure of fluorite, and any type of changes in the ions in this structure changes the intensity and vibrational position of this mode. The Raman spectrum of cerium oxide nanoparticles (Figure 2) shows the F2g mode is positioned at $458 \mathrm{~cm}^{-1}$, which indicates the fluorite structure for these nanoparticles, as discussed in the XRD analysis section. The development of solid solutions via Ce substitution by nickel ions into fluorite structure of $\mathrm{CeO}_{2}$ changed the position and intensity of this mode.
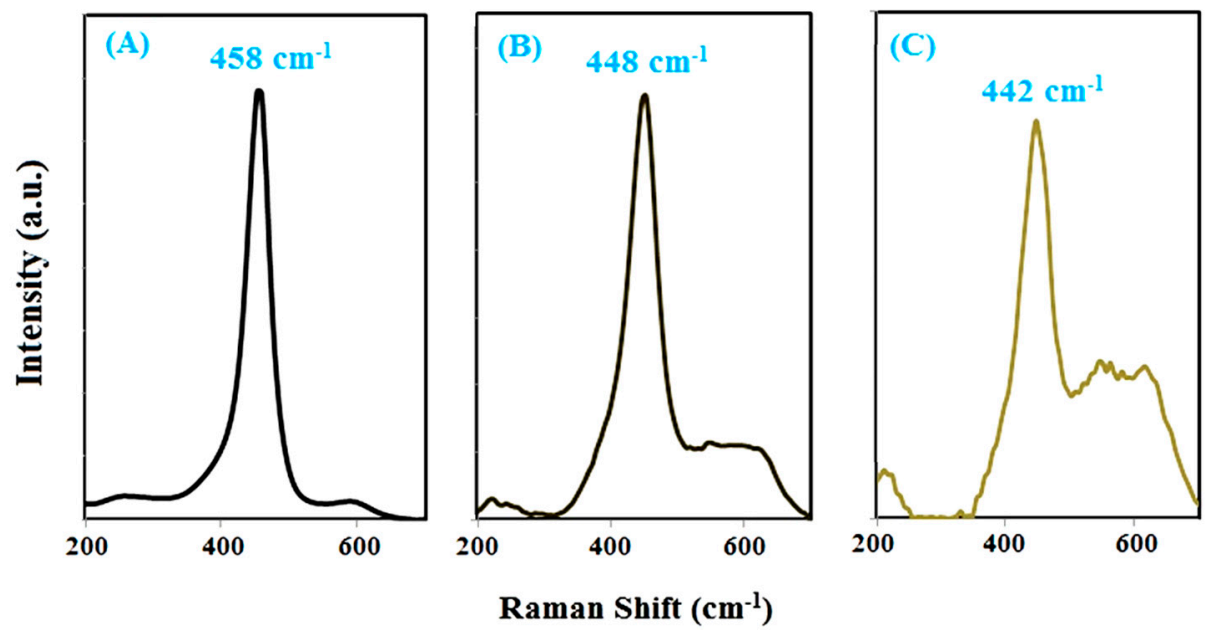

Figure 2. Raman spectra synthesized nanoparticles of $(\mathbf{A}) \mathrm{CeO}_{2}$ and $\mathrm{CeO}_{2}$ doped with $1 \% \mathrm{Ni}(\mathbf{B})$ and $3 \% \mathrm{Ni}(\mathrm{C})$ by using S. rebaudiana extract.

With the increase of doped nickel content, the mode position shifted to lowest values, while its intensity decreased in a substantial way [35]. These find are in accordance with the discussion in the X-ray diffraction section that showed a decrease of crystallinity accompanied of an increase of microstrain level and a decrease in crystallite size.

FESEM images of $\mathrm{CeO}_{2}$ and $\mathrm{Ni}$-doped $\mathrm{CeO}_{2}$ nanoparticles are shown in Figure 3. The spherical shape of the synthesized particles can be seen. The FESEM images further indicate that the size of 
particles was decreased as a function of the increased percentage of Ni doping of the crystal structure. The same conclusion is reached in the XRD discussion.
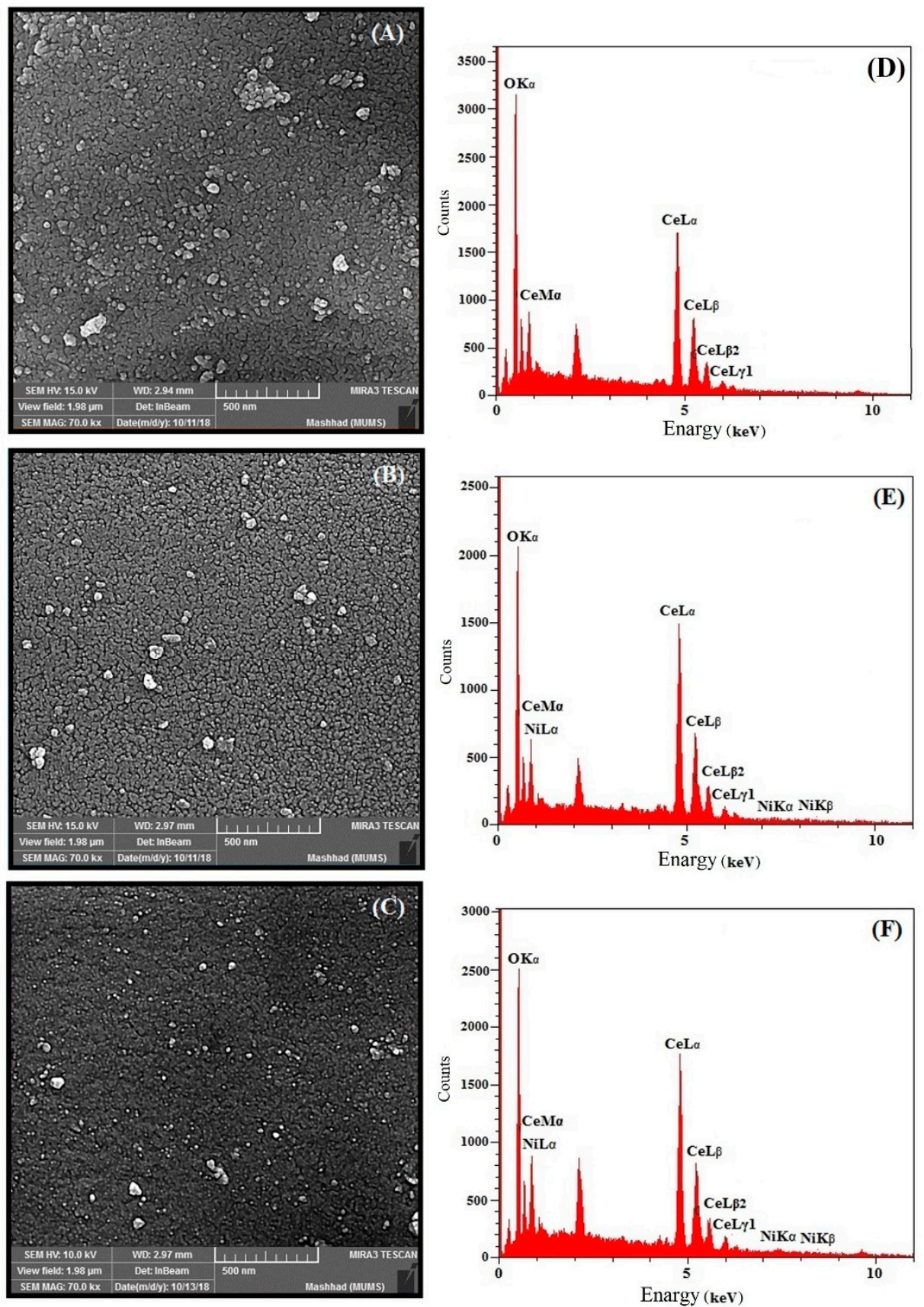

Figure 3. FESEM images of synthesized nanoparticle of (A) $\mathrm{CeO}_{2}$ and $\mathrm{CeO}_{2}$ doped with $1 \% \mathrm{Ni}$ (B), $3 \% \mathrm{Ni}$ and $(\mathbf{C})$; and EDX graph of synthesized nanoparticles of (D) $\mathrm{CeO}_{2}$ and $\mathrm{CeO}_{2}$ doped with $1 \% \mathrm{Ni}$ (E) and $3 \% \mathrm{Ni}(\mathbf{F})$.

Energy-dispersive X-ray spectroscopy (EDX) is an analytical technique used for the elemental analysis or chemical characterization of a sample. This analysis was used to determine the presence of nickel in the structure of cerium oxide nanoparticles. As shown in Figure 4E-H, elemental nickel is clearly observed in the EDX graphs of doped $\mathrm{CeO}_{2}$ nanoparticles, which confirms the presence of nickel ion in the $\mathrm{CeO}_{2}$ nanoparticles. 


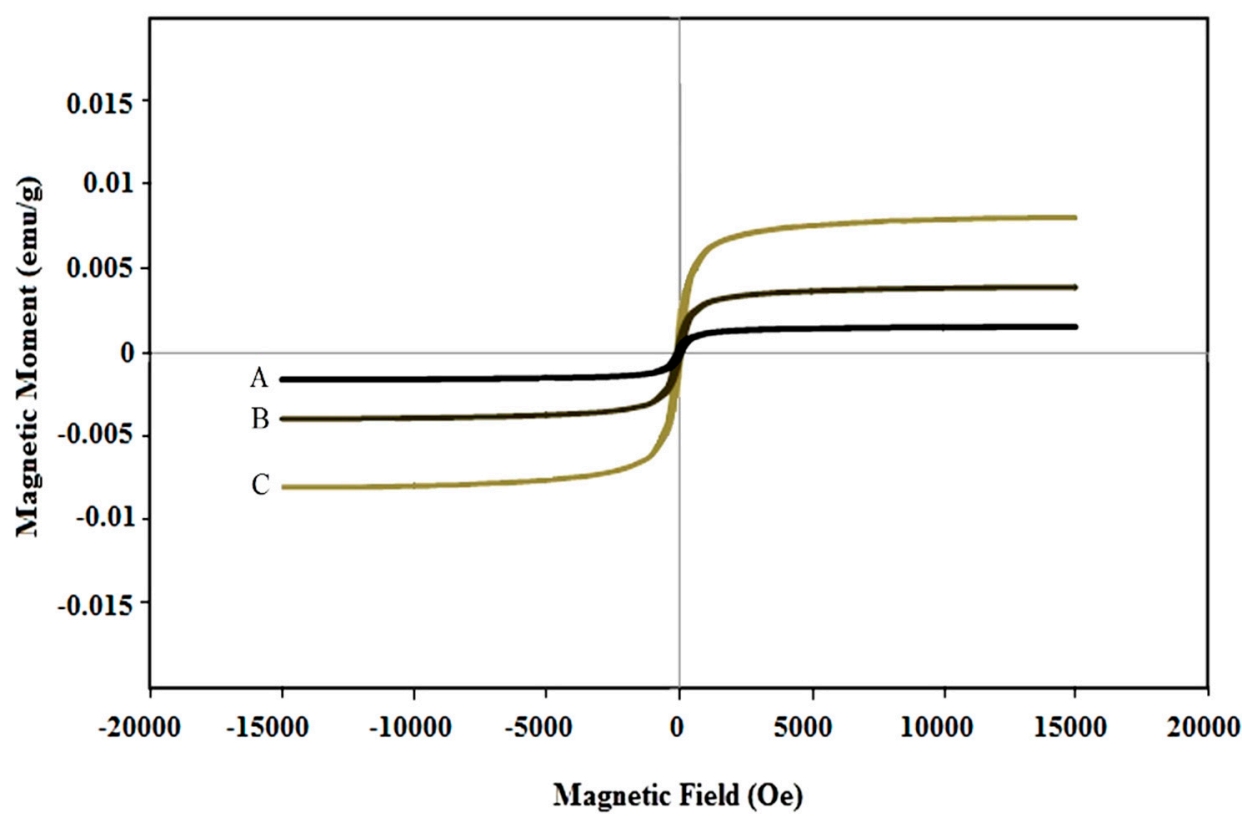

Figure 4. Magnetic hysteresis curves of synthesized nanoparticles of $(\mathbf{A}) \mathrm{CeO}_{2}$ and $\mathrm{CeO}_{2}$ doped with $1 \% \mathrm{Ni}(\mathbf{B})$ and $3 \% \mathrm{Ni}(\mathbf{C})$ by using S. rebaudiana extract.

The magnetic properties of synthesized nanoparticles of $\mathrm{CeO}_{2}$ and $\mathrm{Ni}$-doped $\mathrm{CeO}_{2}$ are shown in Figure 4. The magnetic moment (magnetization) as a function of an applied magnetic field exhibited a paramagnetic-type behavior. However, a close inspection of the curves shows that a slight hysteresis exists and that the hysteresis area is proportional to the Ni cation doping level. Thus, the synthesis procedure allows modulating the magnetic features of nanoparticles. The doping effect on the magnetic properties of nanoparticles is enhanced and gradual increase of the weak ferromagnetic behavior is seen. As shown in Figure 4, the small area of the hysteresis loop of the synthesized nanoparticles is further indicative of a weak ferromagnetic material. This behavior can be understood as a function of the double valence of cerium cations, in addition to $\mathrm{Ni}$ cation insertion in the crystalline lattice of $\mathrm{CeO}_{2}$. In two separate studies, Coey and Sundaresan suggested that increased oxygen vacancies due to the development of reduced cerium $\mathrm{Ce}^{+3}$ from $\mathrm{Ce}^{+4}$ of lattice can increase the interactions between unpaired spins and thus increase the ferromagnetic behavior of $\mathrm{CeO}_{2}$ nanoparticles [36,37].

Sun Protection Factor (SPF) is a standard measurement of the ability of sunscreens to absorb UV rays. By using the spectrophotometric method and Mansur (Equation (1)), one can estimate the value of the SPF parameter for a sample [38]:

$$
\mathrm{SPF}=\mathrm{CF} \times \Sigma \mathrm{EE}(\lambda) \times \mathrm{I}(\lambda) \times \operatorname{Abs}(\lambda)
$$

where the correction factor $(\mathrm{CF})$ is $10, \mathrm{EE}(\lambda)$ is the erythema effect, $\mathrm{I}(\lambda)$ is the intensity of sunlight and $\operatorname{abs}(\lambda)$ is the wavelength absorption. For ease of calculation in this equation, Sayre et al. calculated and presented values of $\operatorname{EE}(\lambda) \times \mathrm{I}(\lambda)$ at 290 to $320 \mathrm{~nm}$ of wavelength as numbers (Table 1).

Table 1. List of the normalized multiplication function values used in calculating the Sun Protection Factor (SPF).

\begin{tabular}{cccccccc}
\hline Wavelength $(\mathbf{n m})$ & $\mathbf{2 9 0}$ & $\mathbf{2 9 5}$ & $\mathbf{3 0 0}$ & $\mathbf{3 0 5}$ & $\mathbf{3 1 0}$ & $\mathbf{3 1 5}$ & $\mathbf{3 2 0}$ \\
\hline EE $\times$ I (Normalized) & 0.0150 & 0.0817 & 0.2874 & 0.3278 & 0.1864 & 0.0837 & 0.0180 \\
\hline
\end{tabular}

After calculation at $10,000 \mu \mathrm{g} / \mathrm{mL}$ concentration, the SPF values were derived as being equal to 38.98, 40.15, 42.54 and 43.47 for non-doped, 1,3 and $5 \% \mathrm{Ni}$-doped $\mathrm{CeO}_{2}$, respectively (see Figure 5). Mineral filters suitable for sunscreens should exhibit particles with two major features, which include 
particle size and band-gap. As a matter of fact, a smaller particle size and a larger band-gap are better for a UV absorber. According to previous studies, the band-gap of $\mathrm{CeO}_{2}$ nanoparticles is larger than that of titanium oxide and zinc oxide nanoparticles, and the synthesized nanoparticles have $8-10 \mathrm{~nm}$ size, so the synthesized nanoparticles can be a better choice for use in sunscreens [39].

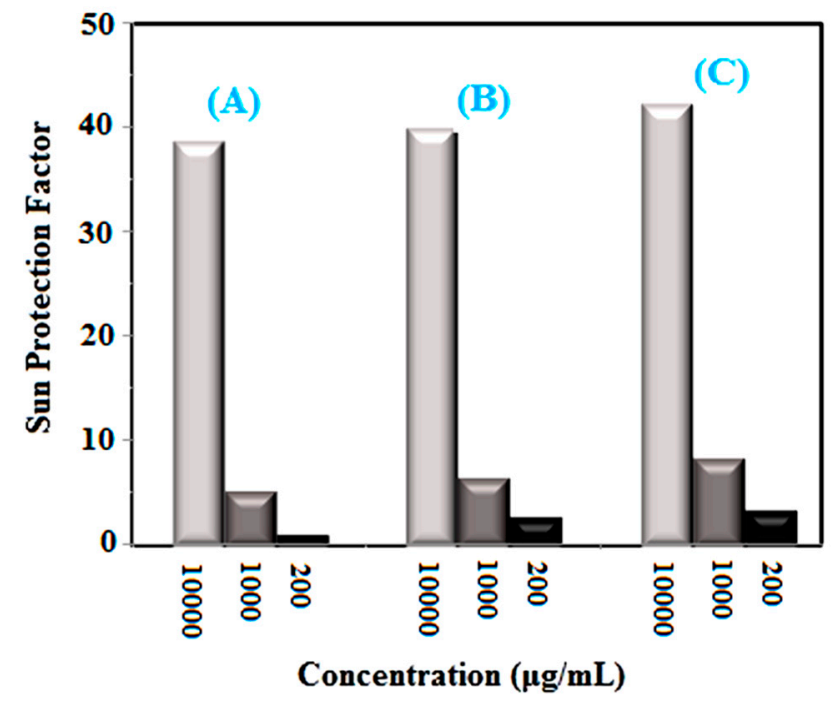

Figure 5. Sun Protection Factor (SPF) of synthesized nanoparticles of (A) $\mathrm{CeO}_{2}$ and $\mathrm{CeO}_{2}$ doped with $1 \% \mathrm{Ni}(\mathbf{B})$ and $3 \% \mathrm{Ni}(\mathbf{C})$ by using $\mathrm{S}$. rebaudiana extract.

\section{Materials and Methods}

\subsection{Chemicals}

The nickel (II) nitrate hexahydrate $\left(\mathrm{Ni}\left(\mathrm{NO}_{3}\right)_{2} \cdot 6 \mathrm{H}_{2} \mathrm{O}\right.$, ) and cerium nitrate hexahydrate $\mathrm{Ce}\left(\mathrm{NO}_{3}\right)_{3} \cdot 6 \mathrm{H}_{2} \mathrm{O}(50 \mathrm{~mL}, 99.99 \%)$ were prepared from Merck, Darmstadt, Germany.

\subsection{Nanoparticle Synthesis}

S. rebaudiana extract acts as a capping and stabilizing agent for the synthesis of nanoparticles, because of the compounds such as terpenoids, alkaloids, and tannins in its leaves. Hence, cerium species can be stabilized by $S$. rebaudiana extract and form nanoparticles. S. rebaudiana leaves were collected, dried and crushed. Powder plant was soaked in distilled water (1:10 ratio). Then, the mixture was centrifuged at $150 \mathrm{rpm}$ for $24 \mathrm{~h}$ and filtered via Whatman paper. In the nanoparticle synthesis, Stevia extract $(10 \mathrm{~mL})$ was diluted with distilled water $(50 \mathrm{~mL})$, and $0.1 \mathrm{M}$ cerium nitrate hexahydrate $\mathrm{Ce}\left(\mathrm{NO}_{3}\right)_{3} \cdot 6 \mathrm{H}_{2} \mathrm{O}(50 \mathrm{~mL})$ was added to the solution. Then $0,1,3$ and $5 \% w / w$ of $\mathrm{Ni}$ to $\mathrm{CeO}_{2}$ was synthesised adding nickel (II) nitrate hexahydrate $\left(\mathrm{Ni}\left(\mathrm{NO}_{3}\right)_{2} \cdot 6 \mathrm{H}_{2} \mathrm{O}\right)$ to the same solution, using individual baths. The solutions were heated up to $80^{\circ} \mathrm{C}$ for $5 \mathrm{~h}$. In the last step, the mixture was dried at $90{ }^{\circ} \mathrm{C}$ giving the precursor powders, which were calcined at $400{ }^{\circ} \mathrm{C}$ during $2 \mathrm{~h}$, in an air atmosphere, using a conventional furnace. A schematic diagram of the major steps of synthesis is show in Figure 6 . Nanoparticles of $\mathrm{CeO}_{2}$ and $\mathrm{Ni}$ doped $\mathrm{CeO}_{2}$ was synthesized by using S. rebaudiana extract. 


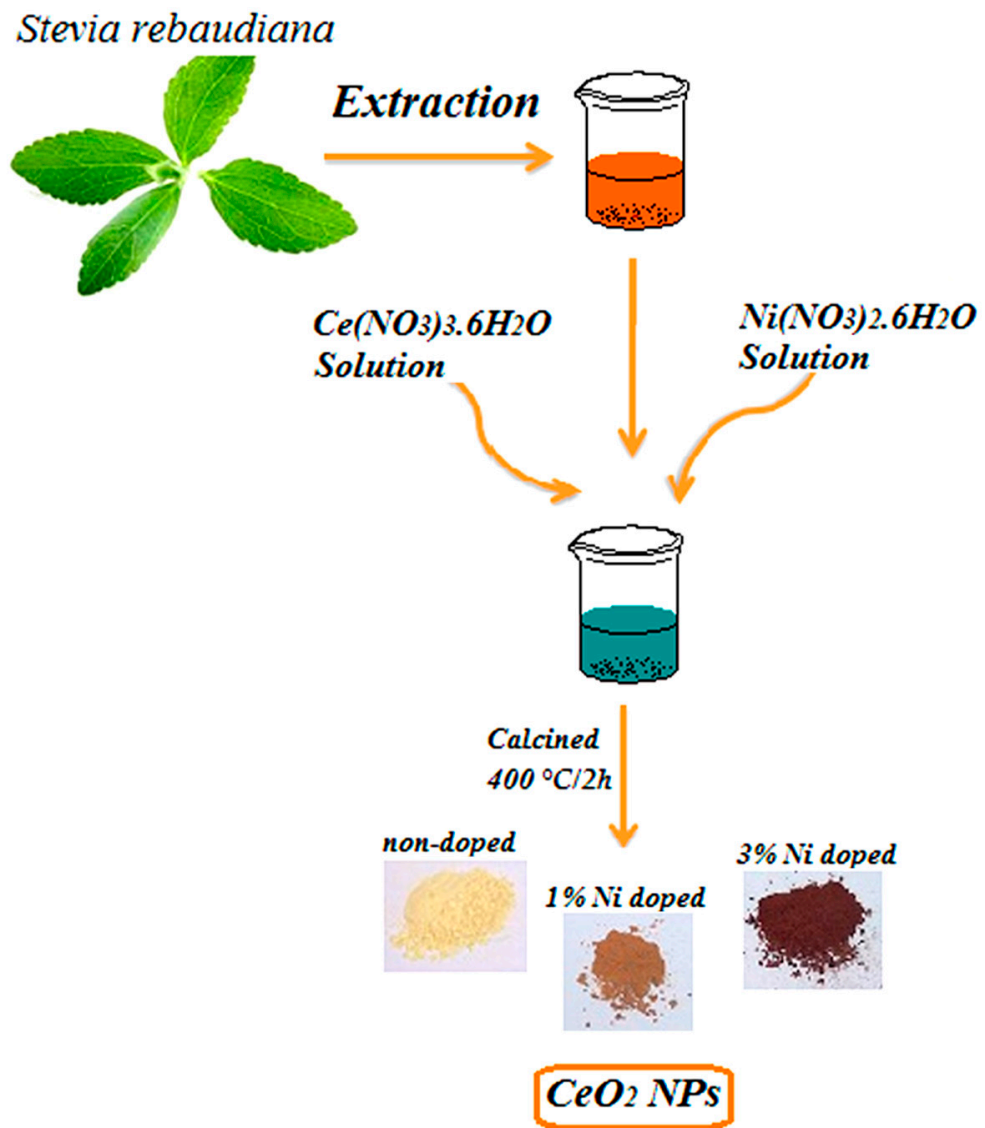

Figure 6. Schematic of the synthesis procedure of $\mathrm{CeO}_{2}$ and $\mathrm{Ni}$-doped $\mathrm{CeO}_{2}$ nanoparticles by using S. rebaudiana extract.

\subsection{Characterization}

The synthesized nanoparticles were characterized through X-ray diffraction on an X'Pert PRO MPD system (PANalytical, Almelo, The Netherlands), by Scanning Electron Microscopy (SEM) using a model MIRA3 instrument (Tescan, Czech Republic), a Raman model Takram P50C0R10 (Teksan, Tehran, Iran) at $532 \mathrm{~nm}$ leaser wavelength, a model Tensor27 FT-IR instrument (Bruker, Optics GmbH, Ettlingen, Germany) and a model 1800 UV-Vis spectrometer (Shimadzu, Kyoto, Japan).

\subsection{Ultraviolet Protection Level of $\mathrm{CeO}_{2}$ and $\mathrm{Ni}$ Doped $\mathrm{CeO}_{2}$ Nanoparticles}

The survey of UV protection of nanoparticles was done by using Sun Protection Factor (SPF) determination in vitro. For purpose the synthesized sample $(1 \mathrm{~g})$ was dissolved using ethanol by ultrasonic irradiation for $15 \mathrm{~min}$, then the prepared solution ( $5 \mathrm{~mL}$ ) diluted using ethanol (50 $\mathrm{mL})$. In following, this solution $(5 \mathrm{~mL})$ was diluted using $25 \mathrm{~mL}$ of ethanol. Absorption values were measured through spectrophotometry in the 290 to $320 \mathrm{~nm}$ range [31].

\section{Conclusions}

Nanometric particles of $\mathrm{CeO}_{2}$ and $\mathrm{Ni}$-doped $\mathrm{CeO}_{2}$ solid solutions were synthesized via a green chemistry route using $S$. rebaudiana extract. Doping of $\mathrm{CeO}_{2}$ nanoparticles leads to the development of ferromagnetic properties. Also, the UV protection property of the $\mathrm{CeO}_{2}$ nanoparticles improved and increased by doping $\mathrm{Ni}$ into the fluorite structure of these nanoparticles, making $\mathrm{Ni}$-doped $\mathrm{CeO}_{2}$ nanoparticles a suitable choice for use in sunscreens.

Author Contributions: M.K. and M.S. conducted experiments, performed data analysis and interpretation, and wrote the paper; M.S., M.A.L.N., and A.I. conceived and designed the study; M.R. conducted experiments; M.A.-A. 
performed data analysis and interpretation; F.M. wrote the paper and provided technical support; F.B. conceived and designed the study, performed data analysis and interpretation, and gave final approval of the manuscript. All authors approved the final version of the paper.

Funding: "This research was funded by Shahid Beheshti University of Medical Sciences and Bam University of Medical Sciences, grant number 98 (M. Khatami Grant)"

Acknowledgments: The authors wish to thank from Hajar Alijani and Iraj Sharifi for their helps.

Conflicts of Interest: The authors declare that they have no conflict of interest.

\section{References}

1. Ferin, J.; Oberdörster, G.; Penney, D.P.; Soderholm, S.C.; Gelein, R.; Piper, H.C. Increased pulmonary toxicity of ultrafine particles I. Particle clearance, translocation, morphology. J. Aerosol Sci. 1990, 21, 381-384. [CrossRef]

2. Lalitha, A.; Subbaiya, R.; Ponmurugan, P. Green synthesis of silver nanoparticles from leaf extract Azhadirachta indica and to study its anti-bacterial and antioxidant property. Int. J. Curr. Microbiol. App. Sci. 2013, 2, 228-235.

3. Ramasamy, V.; Mohana, V.; Suresh, G. The synthesis and characterization of undoped and Ni doped $\mathrm{CeO}_{2}$ nanoparticles using sol-gel method. Int. J. Mater. Sci. 2017, 12, 79-88.

4. Zholobak, N.M.; Ivanov, V.K.; Shcherbakov, A.B.; Shaporev, A.S.; Polezhaeva, O.S.; Baranchikov, A.Y.; Spivak, N.Y.; Tretyakov, Y.D. UV-shielding property, photocatalytic activity and photocytotoxicity of ceria colloid solutions. J. Photochem. Photobiol. B. 2011, 102, 32-38. [CrossRef]

5. Marionnet, C.; Tricaud, C.; Bernerd, F. Exposure to non-extreme solar UV daylight: Spectral characterization, effects on skin and photoprotection. Int. J. Mol. Sci. 2014, 16, 68-90. [CrossRef]

6. Berwick, M.; Pestak, C.; Thomas, N. Solar ultraviolet exposure and mortality from skin tumors. In Sunlight, Vitamin D and Skin Cancer; Springer: New York, NY, USA, 2014; pp. 342-358.

7. Horsham, C.; Auster, J.; Sendall, M.C.; Stoneham, M.; Youl, P.; Crane, P.; Tenkate, T.; Janda, M.; Kimlin, M. Interventions to decrease skin cancer risk in outdoor workers: Update to a 2007 systematic review. BMC Res. Notes 2014, 7, 10. [CrossRef]

8. Mishra, A.K.; Mishra, A.; Chattopadhyay, P. Herbal cosmeceuticals for photoprotection from ultraviolet B radiation: A review. Trop. J. Pharm. Res. 2011, 10, 351-360. [CrossRef]

9. Dao, N.N.; Dai Luu, M.; Nguyen, Q.K.; Kim, B.S. UV absorption by cerium oxide nanoparticles/epoxy composite thin films. Adv. Nat. Sci. Nanosci. Nanotechnol. 2011, 2, 045013. [CrossRef]

10. Hoang, B.T.; Popa, I.U. Innovation in inorganic UV filters in sunscreen. HEPC Today 2014, 9, 35-39.

11. Iranmanesh, T.; Foroughi, M.M.; Jahani, S.; Zandi, M.S.; Nadiki, H.H. Green and facile microwave solvent-free synthesis of $\mathrm{CeO}_{2}$ nanoparticle-decorated CNTs as a quadruplet electrochemical platform for ultrasensitive and simultaneous detection of ascorbic acid, dopamine, uric acid and acetaminophen. Talanta 2020, 207, 120318. [CrossRef]

12. Darroudi, M.; Hakimi, M.; Sarani, M.; Kazemi Oskuee, R.; Khorsand Zak, A.; Gholami, L. Facile synthesis, characterization, and evaluation of neurotoxicity effect of cerium oxide nanoparticles. Ceram. Int. 2013, 39, 6917-6921. [CrossRef]

13. Darroudi, M.; Sarani, M.; Oskuee, R.K.; Khorsand Zak, A.; Hosseini, H.A.; Gholami, L. Green synthesis and evaluation of metabolic activity of starch mediated nanoceria. Ceram. Int. 2014, 40, 2041-2045. [CrossRef]

14. Miri, A.; Darroudi, H.O.S.; Sarani, M. Biosynthesis of cerium oxide nanoparticles and its cytotoxicity survey against colon cancer cell line. App. Organomet. Chem. 2020, 1, 1-8. [CrossRef]

15. Miri, A.; Sarani, M.; Hashemzadeh, A.; Mardani, Z.; Darroudi, M. Biosynthesis and cytotoxic activity of lead oxide nanoparticles. Green Chem. Let. Rev. 2018, 11, 567-572. [CrossRef]

16. Miri, A.; Vahed, H.O.S.; Sarani, M. Biosynthesis of silver nanoparticles and their role in photocatalytic degradation of methylene blue dye. Res. Chem. Intermed. 2019, 9, 164-171. [CrossRef]

17. Khatami, M.; Alijani, H.Q.; Fakheri, B.; Mobasseri, M.M.; Heydarpour, M.; Farahani, Z.K.; Khan, A.U. Super-Paramagnetic iron oxide nanoparticles (SPIONs): Greener synthesis using Stevia plant and evaluation of its antioxidant properties. J. Clean Prod. 2019, 208, 1171-1177. [CrossRef] 
18. Karthik, K.; Nikolova, M.P.; Phuruangrat, A.; Vijayalakshmi, S.; Mahdizadeh, H.; Radhika, D.; Ojiaku, A.; Rherari, V.; Revathi, V.; Verma, U. Microwave-assisted bioengineered CdS nanoparticles for photocatalytic and biological applications. Catalytica 2019, 1, 40-50.

19. Karthik, K.; Shashank, M.; Revathi, V.; Tatarchuk, T. Facile microwave-assisted green synthesis of NiO nanoparticles from Andrographis paniculata leaf extract and evaluation of their photocatalytic and anticancer activities. Mol. Cryst. Liq. Cryst. 2019, 673, 70-80. [CrossRef]

20. Ahmad, A.; Wei, Y.; Syed, F.; Tahir, K.; Rehman, A.U.; Khan, A.; Ullah, S.; Yuan, Q. The effects of bacteria-nanoparticles interface on the antibacterial activity of green synthesized silver nanoparticles. Microb. Pathog. 2017, 102, 133-142. [CrossRef]

21. Shams, S.; Khan, A.U.; Yuan, Q.; Ahmad, W.; Wei, Y.; Khan, Z.U.H.; Shams, S.; Ahmad, A.; Rahman, A.U.; Ullah, S. Facile and eco-benign synthesis of $\mathrm{Au} @ \mathrm{Fe}_{2} \mathrm{O}_{3}$ nanocomposite: Efficient photocatalytic, antibacterial and antioxidant agent. J. Photochem. Photobio. B: Bio. 2019, 199, 111632. [CrossRef]

22. Nasiri, A.; Tamaddon, F.; Mosslemin, M.H.; Amiri-Gharaghani, M.; Asadipour, A. Magnetic nano-biocomposite $\mathrm{CuFe}_{2} \mathrm{O}_{4} @$ methylcellulose (MC) prepared as a new nano-photocatalyst for degradation of ciprofloxacin from aqueous solution. Environ. Health Eng. Manag. J. 2019, 6, 41-51. [CrossRef]

23. Malakootian, M.; Mahdizadeh, H.; Dehdarirad, A.; Amiri-Gharghani, M. Photocatalytic ozonation degradation of ciprofloxacin using $\mathrm{ZnO}$ nanoparticles immobilized on the surface of stones. J. Disper. Sci. Technol. 2019, 40, 846-854. [CrossRef]

24. Dağlıoğlu, Y.; Öztürk, B.Y. A novel intracellular synthesis of silver nanoparticles using Desmodesmus sp. (Scenedesmaceae): Different methods of pigment change. Rend. Lincei. Sci. Fis. Nat. 2019, 30, 611-621. [CrossRef]

25. Minhas, F.T.; Arslan, G.; Gubbuk, I.H.; Akkoz, C.; Ozturk, B.Y.; Asıkkutlu, B.; Arslan, B.; Ersoz, M. Evaluation of antibacterial properties on polysulfone composite membranes using synthesized biogenic silver nanoparticles with Ulva compressa (L.) Kütz. and Cladophora glomerata (L.) Kütz. extracts. Int. J. Biol. Macromol. 2018, 107, 157-165. [CrossRef] [PubMed]

26. Khandannasab, N.; Sabouri, Z.; Ghazal, S.; Darroudi, M. Green-based synthesis of mixed-phase silver nanoparticles as an effective photocatalyst and investigation of their antibacterial properties. J. Mol. Struct. 2019, 36, 3-10.

27. Rahmani, R.; Gharanfoli, M.; Gholamin, M.; Darroudi, M.; Chamani, J.; Sadri, K.; Hashemzadeh, A. Plant-mediated synthesis of superparamagnetic iron oxide nanoparticles (SPIONs) using Aloe vera and flaxseed extracts and evaluation of their cellular toxicities. J. Clean Prod. 2020, 46, 1-12. [CrossRef]

28. Ajdari, M.R.; Tondro, G.H.; Sattarahmady, N.; Parsa, A.; Heli, H. Phytosynthesis of Silver Nanoparticles Using Myrtus communis L. Leaf Extract and Investigation of Bactericidal Activity. J. Electron. Mater. 2017, 46, 6930. [CrossRef]

29. Khatami, M.; Iravani, S.; Varma, R.S.; Mosazade, F.; Darroudi, M.; Borhani, F. Cockroach wings-promoted safe and greener synthesis of silver nanoparticles and their insecticidal activity. Bioprocess Biosyst. Eng. 2019, 42, 2007-2014. [CrossRef]

30. Singh, H.; Du, J.; Singh, P.; Yi, T.H. Role of green silver nanoparticles synthesized from Symphytum officinale leaf extract in protection against UVB-induced photoaging. J. Nanostructure Chem. 2018, 3, 359-368. [CrossRef]

31. Miri, A.; Sarani, M. Biosynthesis, characterization and cytotoxic activity of $\mathrm{CeO}_{2}$ nanoparticles. Ceram. Int. 2018, 4, 12642-12647. [CrossRef]

32. Abbas, F.; Jan, T.; Iqbal, J.; Ahmad, I.; Naqvi, M.S.H.; Malik, M. Facile synthesis of ferromagnetic Ni doped $\mathrm{CeO}_{2}$ nanoparticles with enhanced anticancer activity. Appl. Surf. Sci. 2015, 357, 931-936. [CrossRef]

33. Sathyamurthy, S.; Leonard, K.J.; Dabestani, R.T.; Paranthaman, M.P. Reverse micellar synthesis of cerium oxide nanoparticles. Nanotechnology 2005, 16, 1960-1964. [CrossRef]

34. Murugan, R.; Vijayaprasath, G.; Mahalingam, T.; Ravi, G. Enhancement of room temperature ferromagnetic behavior of rf sputtered $\mathrm{Ni}-\mathrm{CeO}_{2}$ thin films. Appl. Surf. Sci. 2016, 390, 583-590. [CrossRef]

35. Coey, J.M.D.; Venkatesan, M.; Stamenov, P.; Fitzgerald, C.B.; Dorneles, L.S. Magnetism in hafnium dioxide. Phys. Rev. B 2005, 72, 024450. [CrossRef]

36. Sundaresan, R.; Bhargavi, N.; Rangarajan, U.; Siddesh, C.N.R. Ferromagnetism as a universal feature of nanoparticles of the otherwise nonmagnetic oxides. Phys. Rev. B 2006, 74, 161306. [CrossRef]

37. Donglikar, M.M.; Deore, S.L. Sunscreens: A review. Pharm. J. 2016, 8, 171-179. [CrossRef] 
38. Boutard, T.; Rousseau, B.; Couteau, C.; Tomasoni, C.; Simonnard, C.; Jacquot, C.L.J.; Coiffard, M.; Konstantinov, K.; Devers, T.; Roussakis, C. Comparison of photoprotection efficiency and antiproliferative activity of $\mathrm{ZnO}$ commercial sunscreens and $\mathrm{CeO}_{2}$. Mater. Lett. 2013, 108, 13-16. [CrossRef]

39. Jose, J.; Netto, G. Role of solid lipid nanoparticles as photoprotective agents in cosmetics. J. Cosmet. Dermatol. 2019, 18, 315-321. [CrossRef]

Sample Availability: Samples of the compounds are available from the authors.

(C) 2019 by the authors. Licensee MDPI, Basel, Switzerland. This article is an open access article distributed under the terms and conditions of the Creative Commons Attribution (CC BY) license (http://creativecommons.org/licenses/by/4.0/). 